\title{
Essays on the history of Brazilian dipterology. III. Three remarkable notices from the 18th century, mainly related to myiasis-producing flies (Cochliomyia and Dermatobia)
}

\author{
Nelson Papavero ${ }^{1,3} \&$ Márcia Souto Couri ${ }^{2,3}$
}

\begin{abstract}
'Museu de Zoologia, Universidade de São Paulo, Caixa Postal 42.494, 04218-970 São Paulo-SP, Brasil.nelson.papavero@pq.cnpq.br ${ }^{2}$ Museu Nacional, Universidade Federal do Rio de Janeiro. Quinta da Boa Vista, s/nº, 20940-040 Rio de Janeiro-RJ, Brasil. courimarcia@gmail.com ${ }^{3}$ Conselho Nacional de Desenvolvimento Científico e Tecnológico (CNPq), fellow.
\end{abstract}

\begin{abstract}
Essays on the history of Brazilian dipterology. III. Three remarkable notices from the 18th century, mainly related to myiasis-producing flies (Cochliomyia and Dermatobia). This paper registers reports about dipterans made by three Portuguese who lived in Brazil during the $18^{\text {th }}$ century. Luiz Gomes Ferreira, in his book "Erário mineral" ["Mineral revenue"], wrote curious passages related with myiasis-causing flies of the genus Cochliomyia. José Rodrigues de Mello registered, in Latin verses, the folklore for curing myiases caused by Cochliomyia hominivorax in cattle. Luiz dos Santos Vilhena, in the last of his twenty letters dealing with several aspects of life in Brazil, made reference to horseflies, human bot flies and mosquitos.
\end{abstract}

KEYWORDS. Brazil; Dipterology; History; 18th century; Cochliomyia; Dermatobia; mosquitoes.

RESUMO. Ensaios sobre a história da dipterologia brasileira. III. Três notáveis notícias do século XVIII, principalmente relacionadas a moscas produtoras de míases (Cochliomyia e Dermatobia). Este trabalho registra notícias sobre dípteros feitas por três portugueses que moraram no Brasil durante o século XVIII. Luiz Gomes Ferreyra, em seu livro "Erário mineral", escreveu curiosas passagens principalmente relacionadas com moscas causadoras de miíases do gênero Cochliomyia. José Rodrigues de Mello registrou, em versos em Latim, o folclore para curar bicheiras causadas por Cochliomyia hominivorax no gado. Luiz dos Santos Vilhena, na última de suas vinte cartas sobre vários aspectos da vida no Brasil, fez referência a mutucas, bernes e mosquitos.

PALAVRAS-CHAVE. Brasil; Dipterologia; História; século XVIII; Cochliomyia; Dermatobia; Mosquitoes.

\section{The Erário mineral ["Mineral Revenue"] of Luiz Gomes Ferreyra (1735)}

Luiz Gomes Ferreyra was Portuguese, born in the Vila de São Pedro de Rates. In his youth he went to Lisbon, where he became a barber-surgeon under the direction of Francisco dos Santos, a surgeon of the Enfermaria Real de Dom Pedro. He completed his formation in the Hospital Geral de Todos os Santos in Lisbon. After undertaking several voyages to India and Brazil, serving as a surgeon, he established himself in 1708 in Salvador, Bahia, where he remained until 1710. He then moved to Minas Gerais, residing successively in the cities of Sabará, Mariana and Vila Rica. In 1711 he was integrated as a surgeon, in the army recruited to expel the French fleet that had invaded Rio de Janeiro. In 1731 he returned to Portugal, publishing in 1735 his Erário mineral, where he related his medical experience obtained during his residence of 23 years in Brazil.

In this book, the fifth medical work written in Brazil, two interesting passages are found about dipterans. In translation:

\footnotetext{
"For growing hair on the head or other parts. It is a confirmed experience that the head, shaved with a razor four or five times and anointed with the suet of a quartered man, or with its oil, for the period of one month, makes the hair grow; and if the head is anointed with the aforesaid
}

suet for two months, the hair will grow so much that one will never wish for more; it also removes stains and marks left by smallpox, anointing [the skin] every day, twice a day, with the said suet or its oil; it also eliminates the scars left by wounds in the face or the hands; it [the suet] is sold in some drugstores, sold by the executioners; but must be applied as soon as possible, or at most a little after. Also anointing the part with honey mixed up with the powder of flies [our emphasis] several times" (Ferreyra 1735: 148).

"[Medicine] for water, or animal, or any other thing entered in the ear. If what entered was water or some other liquid thing, it can be remedied introducing a straw inside it and sucking with the mouth through the straw with all possible force; the liquid which is inside will come out; if what entered in the ear was a flea, put inside the ear a small ball made with cat's or dog's hairs, as through its sympathy the flea will cling to the ball; but if it does not come out, fill the ear with hot oil, and presently the flea, fly or bedbug will die, or also boiling water. If it is the spider called rotella [Salticidae], which is the one which catches flies, you will put near the ear a fly held by its legs, because with the buzzing of its wings the spider will soon come out to catch it [our emphasis]; and if it was some other animal, put inside the ear hot water mixed 
with rue or peppermint juice, or yet spearmint, and the animal will come out, living, or dead" (Ferreyra 1735: 167).

But the most interesting part of his book, as regards dipterans, deals with the myasis-causing flies of the genus Cochliomyia (Ferreyra 1735: 392-399). In translation:

\section{"CHAPTER XII. Of the maggots of blowflies in the nose or other parts and their observation.}

1. This disease is very common in Minas Gerais both in negroes and whites, and many white and black people have died of it in large numbers, because there are many blowflies and they are attended too late.

2. These flies have a bluish color and feed upon garbage, rotten meat and filthy liquids, and lay their eggs in the clothes, or in wounds and ulcers, there being humidity, or in the nose of a sleeping person, or even when awake, but being dirty, as happens with some negroes and also some whites; and the flies begin to eject from their mouth [sic] some white eggs which, in a short time, begin to move and originate animated maggots which, while still young, die very easily with any remedy applied against them, but afterwards, when grown up (which happens in a few days) it is harder and more difficult to kill them, especially when they are placed in their homes or caves ["cavernas" in the original text; we have adopted a literal translation], which they build, where it is not so easy for the remedies to penetrate, and even if these reach them, and the remedies not being applied for some time, they will not die, unless the medicine is frequently administered.

\section{With which medicines are they killed.}

3. If there be maggots in some sore or wound, one has to try to kill them before they grow up and form caves, with the juice of green [leaves of] tobacco, mixed up with an equal part of strong vinegar and a few grains of salt, soaking with it threads and wisps; first this remedy has to be injected into the caves by means of a syringe, the patient conveniently positioned so that the remedy will run into the place where the maggots are, and then adding the [soaked] threads and wisps; if it does not result, mix in this medication pipe's dottle [sarro de cachimbo], liquefying it very well; although it is difficult to dissolve, it always has much virtue; or soak the threads and wisps with the same dottle, as it is an effective medicine wherever it reaches; the patient must be placed in such a position that the medicine may flow to the place where the maggots are - this is as necessary as the remedy itself, because if the medicine is not conveniently applied, the maggots remain unaffected and the patient useless or lifeless.

4. Those maggots enter principally through wounds or sores exposed to the air and uncovered; they are more abundant in the negroes, after they are whipped in the buttocks, the flesh becoming exposed, being afterwards ignored and the wounds neglected, because their masters put them in chains and make them work, although they are even inca- pable of walking; many of them are lost, some because the maggots eat up their flesh and corrupt their bones, causing mortal accidents; some others because those parts are lost, as they become gangrenous and rotten; I have seen many persons suffering from either manner; some I have remedied, some others not, because they were attacked by herpes, dying miserably; it is a lamentable loss and a lack of fear of God to let them die so forsaken. But let's proceed to the most dangerous ones, which are those that penetrate through the nose.

\section{With which medicines they must be treated, when entering by the nose.}

5 . This genus of infirmity is very terrible and very difficult to cure, especially when several days have elapsed, and the maggots have become large, having proceeded upwards or sideways; being larger, they are harder to kill; if they have moved upwards or towards one of the sides, they are more troublesome to kill, as it is more difficult for the medicine to reach them, unless applied with much industry; and because the remedy affects only the first maggots, being unable to exert its function much farther; the maggots, when grown up, are so packed together that, even if the medicine is effective, it affects only the first ones; this I have observed several times; and this is why I say that this infirmity is terrible and difficult - because the maggots, being large, are stronger and do not easily die.

6. I have sometimes observed that the larger maggots do not easily die when reputedly good medicines are applied; the reason is that, extracting some of them alive in some occasions and placing them in the remedy with which I used to cure them, they did not die in a short time; in other occasions, when I was curing some infestation of maggots in wounds caused by whipping, after removing those I could, I applied the remedy over the remaining ones, and saw that the uppermost ones were some dead, others contaminated by the remedy - because they became yellowish; but most of them, where the remedy had not penetrated, presented their natural color, their strength and vigor, because they were closely packed, as said above.

7. I was at first oftentimes mistaken that the pains, weight or swellings of the head were due to some other cause and not to the penetration of the maggots by the nose; because of this lack of knowledge, I used to prepare other types of medicines, whereas the maggots were growing, contaminating the entire interior. As bloody excretions oozed from the nose, I then became aware that there were maggots, this being the best sign of their presence and the best indication of these parasites. Accordingly, when I saw a patient with a heavy head, pains in the eyes and a weight in them, or in the head, or a swelling in some side of the nose, I examined the patient with further detail and attention, asking him whether he felt something biting him above the nose, or moving around it, and groping his face near the eyes, pressing the place in order to observe if there was pain; if it was a negro, I asked whether he already got maggots in the nose, because if some- 
body had them once, it is easier to have then again; I further inquired whether some humidity was oozing, or had oozed, from the nose, with a foul odor, or bloody - because these two signs of some bloody or foul-smelling humidity oozing from the nose are very common and sure signs; the foul odor proceeds from the corruption and rottenness of the place where the maggots are and the blood from some veins, great or small, torn by the maggots, whence more or less blood comes, it being impure because it is mixed up with that humidity. Once this is ascertained, that there are maggots which entered through the nose, they must be killed with the medicines specified below.

8. Macerate green leaves of tobacco and peppermint, as many as are sufficient to produce two ounces, strained through a piece of cloth; add two ounces of very strong vinegar and some drops of vitriol spirit and some grains of minced salt; this medicine will be poured in with a spoon, the patient lying on his back, with the chin well raised, remaining in that position as long as he can, so that the remedy may penetrate the ways, or caves, made by the maggots, until it reaches them, destroying them; if one is sure that some maggots are located in the sides [of the nasal cavity], after the patient has lain on his back, with the chin well raised up, he must be turned over that side, where the maggots are, so that the remedy may go directly onto them, the said remedy being applied every two hours, and always administered hot.

9. This medicine is not only able to kill the maggots, but also of curing the wounds made by them, and efficient against the rottenness and foul odors that always exist where there are those maggots; much attention has to be paid to extract some maggot which, forced by the medicine, tries to escape from it, for which purpose some person must remain besides the patient, because the maggots may suddenly appear, but retreat once again very fast; attention must also be paid to the mouth, because some of them may pass to it; if any pain or swelling appear in the palate, or some small tumor, they must be opened up with a lancet, where the worms bore into it, as the patient will retain those holes forever, with a raucous voice and difficulty in pronouncing words; this will not succeed if the palate is opened with a lancet; the remedy must be continually applied, in one and the other parts, with a syringe, always removing the maggots that appear, forced by the medicine.

10. However, if this remedy, applied during two days, does not produce the desired effects, we will prepare another, in the following manner. Strained juice of green leaves of tobacco, one ounce; water, where half a span of shag, from which tobacco is obtained for smoking, is dissolved and rubbed in the aforesaid water, two ounces of it; strong vinegar, two ounces; salt from Portugal, two eighths-of-an-ounce, macerated and dissolved in the same medicine; some drops of vitriol spirit; this remedy will be poured with a spoon in one and the other parts, the patient being ordered to procure the best position for the medicine to penetrate and find the part, or parts, where the maggots are located.

11. In case of great necessity, when there is a menace of danger, in this case it must be added to the remedy a portion of pipe's dottle, found inside the stem of a smoking pipe, and also some ashes of the tobacco that was burned, and the all thing will be dissolved, as well as possible; although it is very difficult to liquefy, it always adds a great virtue to the remedy, for being very strong; this must be done while the remedy is hot, dissolving that mixture with a spoon; don't mind whether it is not entirely dissolved, because it is venomous and able to kill according to the quantity; but in the right measure [the only portion that will be dissolved], there is no danger. In order to illustrate the effect of the dottle, I include the following observation.

12. In the Villa Real do Sabará, Manoel Soares, having had crab lice [Phtirus pubis] on his lower parts, was advised to anoint those parts with the aforesaid dottle; and as he was careless, he took his finger to his nose, and with the respiration he took the terrible, loathsome and venomous odor to the nose, and all of a sudden fainted, becoming speechless for over five hours, completely absent minded, with only a feeble and tenuous respiration and a pulse so thin as a hair from the head; after that lapse of time nature started to win over that venomous aura and he very slowly recovered; I witnessed the whole thing without having been called; he himself confessed afterwards that which I referred; and to him, without knowing the cause of the accident, nor any person from his household, I poured into his mouth, with much trouble, triaga magna dissolved in wine.

13. Because of that, and because I have had other experiences of its effects, it seems to me that, there being maggots in the nose, threads with pipe's dottle should never be used, as some curious people do when there are maggots in other parts; because, as everybody knows, wherever it reaches, it destroys them; the dottle must be ultimately used only when added to some other medicine, or against those maggots that become retained, that is, when they are difficult to reach and large. It may endanger the life of the patient, as has happened with the priest nicknamed, by antonomasia, Canjica [maize porridge], an inhabitant of Ribeirão Abaixo, who lost his life due to fly's maggots which penetrated his nose, and some other people; it is therefore necessary that the medicine be applied frequently, with the utmost care; and for further clarity, I add the following observation.

\section{A unique observation of maggots in the nose in one of my slaves.}

14. In the year 1730 it happened that flies' maggots entered the nose of one of my slaves; he complained that he had a headache and therefore I ordered him to take baths and use the erva-de-bicho [Polygonum acre, Polygonaceae], thinking he had haemorrhoids; but his complaints increasing, and I, uncertain of which remedy I would give him, some of his companions told me that this negro had eliminated through the nose a reddish secretion; when asked about this, he confirmed the fact; through this sign I perceived that there were flies' maggots, especially because his complaints were growing. I gave him at first a medicine, thinking that the maggots were still small, and that the remedy would be enough; but as not one of them appeared and his complaints augmented, 
with a great increase of weight in the head and a fever caused by their agitation trying to escape from the medicine, eating and boring furthermore with greater strength, I had recourse to another, stronger remedy; with it some large maggots began to exit, with a yellowish color, affected by the remedy, some tumbling upon the bed, others regaining the interior.

15. Therefore, seeing that the remedy was operating too slowly and that the maggots were large, and that the complaints were growing, in such an important member as the head, and the slave being valued four hundred pieces of eight, his life in great danger, I was uncertain as to which remedy should be applied; on one hand, considering that the pipe's dottle was venomous; on the other, that the danger was imminent, his face and eyes very swollen, and the intermittent pulse, I decided to prepare a medicine with the dottle, such as has been described above, the which, applied frequently, under the conditions just explained, had a marvelous effect; because, as it was being applied, the maggots were either dying, or exiting, and others, stronger ones, were escaping to the outside, the remedy applied to the patient lying upon his back with the chin well raised up, after one day applying this medicine, he began to complain of a pain in his mouth; I ordered him to open it and saw in the palate a hole swarming with maggots, so many and so packed together, that I was baffled, with a kind of veil or film above them, through which they could be seen; I ripped that film and perceived more clearly that multitude, with so much foam, threads and fragments, so loathsome and with such a foul odor that caused horror in all those who have seen it. I endeavored with the utmost brevity to take them out with a forceps, and extracted over fifty.

16. Through one and the other parts I syringed the aforesaid remedy, and from one and the other the maggots were coming out, dead or alive, I extracting some of them and cutting with the point of a scissors the threads or fragments of the hole, frequently applying the medicine; some maggots tumbled from the nose over the bed, others inside the mouth; thus were they coming out forced by the remedy; one application ended, I prepared another, and the maggots were becoming extinguished; the face swelling was diminishing, the pulse becoming more regular; the hole in the palate became cleaner and healed; but the hole remained open and round, in the middle of the palate, and because of this the negro remained with a raucous voice; but the most important thing was to place the patient in such a position that the medicine would run towards where the maggots were, having thus time enough to exert its power.

17. Note. This negro did not feel the maggots in his mouth because, being a robust man, very few things annoy him; and also because this kind of people is always somewhat savage; and although some are clever and practical, they always show, as regards certain things, something of the brutes. He had fever, with intermittent weakening of the pulse; he had the face and the eyes very swollen and some delirium. The pain, the weight in his head were great; the maggots entered when he was asleep, during the day, in the open; the flies alighted on some humidity he had coming out from his nose; in no time the maggots eclosed from the eggs the flies laid from their mouth [sic], as I said in the beginning of this chapter".

\section{José Rodrigues de Mello's poem about cattle myiasis (1781)}

José Rodrigues de Mello was a Jesuit priest, born in the city of Oporto, Portugal. Expelled from the Society of Jesus in 1759 , he went to live in Rome, apparently until the year 1780. He eventually came to Brazil, living in the state of Bahia at least until 1817 (Silva 1860: 116). He published De rusticis Brasiliae rebus carminum libri iv (Mello 1781; another edition in 1798), where, in the chapter entitled De cura boum in Brasilia (about cattle raising in Brazil), he documented, in Latin verses, the folklore for curing myiases caused by Cochliomyia hominivorax in cattle (Mello 1781: 127, 1798: 38-39):

\footnotetext{
"Non minus in teneros vaccarum saevit alumnus Muscarum fatale genus; nam molle vitelli Abdomen fodicat medium teterrima pestis, Progeniemque malam vermes ibi linquit edaces, Ulcere qui penetrant vel viscera ad usque profundo, Exitiumque ferunt misero, nisi forte ministri Accurrant, promptoque aegrum medicamine curent. Ne patere, ut quisquam [manque id sollemne bubulcis] Carmina nescio quae mussans, digitisque figuram Ter crucis effingens super ulceris ore, caducos Devoveat vermes: sit praesentissima quamvis Haec medicina malo, pestemque elininet omnem, Secretis ne fide dolis, nam forsitan illis Abjectis igitur, quae relligione vetantur, Auxiliis, sincera gregi medicamina prome. Fac servi religent aegros ad lignea septa, Excutiantque manu vermes, herbaque salubre Turpe fricent ulcus; tum pinguem ex paupere cornu Infundant, ricini sudat quem bacca, liquorem. Inspiciant quoque num linguae summoque palato Haerescat pestis, nam pestem buculus illuc Invenit adlambens, quae prurit vermibus, alvum".
}

João Gualberto Ferreira Santos Reis published a translation of that book (Reis 1817; in Amaral \& Melo 1941). The verses related to Cochliomyia are as follows (Reis in Amaral \& Melo 1941: 331-332):

Classe maligna de nojentas Moscas Não menos dano causa aos bezerrinhos; Já no meio do abdómen os penetra A letal peste, já progênie imensa Ali derrama de famintos Vermes; Que na chaga estendendo-se ao interno, O interno irão roendo ao miserável Até murchar-lhe a vida, se propícios Cuidadosos serventes não lhe acodem, Com súbito remédio o mal vedando. Mas não consintas que Impostor infame, 
Não sei que vozes fátuo murmurando, (Superstição solene entre os Vaqueiros) $E$ vezes três de cruz fingindo a fórma Co'a mentirosa mão sobre a ferida. Os caducos conjure imundos Vermes; Surta embora tal cura ótimo efeito; Embora desarreigue, extinga a peste; No recôndito embuste não confies: Talvez disfarce nele o seu veneno O Tartáreo Dragão, de enganos fértil.

Detestados assim os criminosos Remédios, que repugna a Fé mais pura. Os lícitos sòmente ao gado exibe.

Faze com que os Servos nos cercados atem

Os bezerros molestos; e extrahindo

Os ímpios Vermes, com salubres hervas

Proveitosa fricção à chaga apliquem:

Depois lhe infundam a substância oleosa.

Que usa a baga verter da Mamoneira.

Indaguem outrossim, se os bezerrinhos

Aferrada na língua, ou entre as rugas

Têm do sumo palato a indigna peste;

Que eles mesmos ali néscios conduzem.

Indo a chaga lamber, que os Vermes comem."

In a free translation:

Malignant class of abject flies, they cause serious damage to the little calves; in the middle of the abdomen the lethal pest penetrates them, and an immense generation of famished maggots pass from the wound to the internal parts, eating away the internal organs of the miserable calves, until their life wanes, if solicitous and careful servants do not assist them with an immediate medicine that prevents this evil.

But do not allow infamous impostors, I know not which empty words mumbling (a solemn superstition among cowboys) and thrice feigning, with a deceitful hand, the shape of a cross over the wound, to conjure the filthy and tumbling maggots; and although this cure obtains an excellent result [because the maggots will anyway abandon the body] extirpating and extinguishing the pest, do not trust the hidden trickery - maybe in it is hidden the venom of the Tartarean Dragon [the devil], so full of deceptions.

Once thus abhorred the criminal remedies rejected by the purest Faith, only the licit ones apply to the cattle; order the servants to tie, inside the corral, the sick calves, extracting the impious maggots, and with healthy herbs apply salutary rubbings over the sore, afterwards pouring into them the oily substance that the castor bean uses to exudate.

Inquire, furthermore, whether the little calves have, stuck into their tongue, or among the furrows of their palate, that disgraceful pest, which the calves themselves ignorantly lead thereto, by licking the sore and swallowing the maggots.

Similar sympathies and methods for healing cattle myiases were and are still used in Brazilian folklore (cf. Lenko \& Papavero 1997: 343-352).

\section{The Recopilação of Luiz dos Santos Vilhena (1799)}

Luiz dos Santos Vilhena was born in Portugal in 1744. In 1787 he was appointed Royal Professor of Greek in Salvador, Bahia, where he died in 1814. In1798 and 1799 he wrote twenty letters dealing with several aspects of Brazil, the entire manuscript being completed in 1802. In his Letter XX, most probably written in 1799 (Vilhena 1802: 414-531) he dealt with Brazilian animals. On pages 440 and 441 he spoke about some Diptera. In translation:

"It will not be possible to list the many kinds of horseflies that in some regions are called mutucas, which have such a penetrating sting [sic; mouthparts] that look like splinters; the same happens in relation to the different kinds of unbearable flies and mosquitoes found in almost all regions of Brazil and very especially at the mouth of the Xingu river, one of those rivers that, crossing the unknown wildernesses of the American domains, flows into the Amazon, and that pest is there so abundant that it almost kills those who navigate it. There are some flies which, alighting upon animals, drop a maggot which penetrates into the skin, there growing until becoming a hairy worm, called berne, and the natives call it ura. The house mosquitoes are here called muriçocas. In the mud below mangroves and in the margins of the rivers near the coast swarms are bred of small, almost invisible mosquitoes called meruins, which during the 'marés de lançamento' [tides occurring in period of crescent and waning moons] bite desperately, leaving an itching similar to that produced by nettle".

\section{REFERENCES}

Amaral, P. do \& J. R. de Melo. 1941. Geórgicas brasileiras (Cantos sobre coisas rusticas do Brasil) (1781). Versão em linguagem de João Gualberto Ferreira dos Santos Reis. Biografias e notas de Regina Pirajá da Silva. Rio de Janeiro, Academia Brasileira de Letras, xi+395 p.

Ferreyra, L. G. 1735. Erario mineral dividido em doze tratados, dedicado, e offerecido á purissima, e serenissima Virgem Nossa Senhora da Conceyçaõ. Autor Luis Gomes Ferreyra, cirurgião approvado, natural da Villa de S. Pedro de Rates, e assistente nas minas de ouro por discurso de vinte annos, Lisboa Occidental, Officina de Miguel Rodrigues, Impressor do Senhor Patriarca, 548p.

Lenko, K. \& N. Papavero. 1997. Insetos no folclore. $2^{\text {a }}$. edição (revista e ampliada), São Paulo, Plêiade \& Fundação de Amparo à Pesquisa do Estado de São Paulo, 467 p.

Mello, J. R. de. 1781. Josephi Rodrigues de Mello lusitani portuenses De rusticis Brasiliae rebus carminum libri iv. Accedunt Prudenti Amaralii brasiliensis De Sacchari opifício carmen. Roma, Typographia Fratrum Puccinelliorum, 206 p.

Mello, J. R. de. 1798. Josephi Rodericii Melii De rebus rusticis brasilicis carminum libri quatuor. Quibus accedit Prudentii Amaralii De Sacchari opifício singulare carmen, jussu, et auspiciis regiae suae celsitudinis Brasiliae Principis, domini nostri denuo typis mandati, curante Fr. Josepho Mariano a Conceptione Velloso, strictioris observantiae S. Francisci Fluvii Januarii. Olysiponae [= Lisboa], Typographia Patriarchali Joannis Procopii Correae Silvii, 113 p.

Reis, J. G. F. dos S. 1817. De cura boum in Brasilia latino carmine deducta auctore Josepho Rodrigues de Mello lusitano portuensi. Ao illustrissimo e excelentissimo Senhor Conde dos Arcos (...). Traducção portuguesa do poema bucolico de José Rodrigues de 
Mello, lusitano portuense, feita, offerecida, e consagrada por João Gualberto Ferreira dos Santos Reis, professor regio da lingua latina da Freguezia do Senhor do Bom-fim da Mata de S. João, natural desta cidade da Bahia. Bahia [= Salvador], Typogr. de Manoel Antonio da Silva Serva, viii $+96 \mathrm{p}$

Silva, I. F. da. 1860. Diccionario bibliographico portuguez. Estudos de Innocencio Francisco da Silva applicaveis a Portugal e ao Brasil. Tomo quinto, Lisboa, Imprensa Nacional, $472 \mathrm{p}$.

Vilhena, L. dos S. 1802. Carta XX em que se dá huma breve, e recopilada noticia dos tres Reinos, Annimal, Vegetal, e Mineral no Estado do Brazil, indicando alguns prestimos de Arvores, e plantas tanto para a Construcção naval, civil, e ainda Comercio, como para Marcenaria, Tintoraria, e Medicina; finalizando com a noticia dos Mineraes que no
Brazil se tem descuberto, o que melhor se verá pello Contexto da mesma Carta, p. 414-531, in seu Recopilação de Noticias Soteropolitanas e Brasilicas contidas em XX Cartas, que da Cidade do Salvador, Bahia de Todos os Santos escreve hum a outro Amigo em Lisboa, debaixo de nomes alusivos, noticiando-o do Estado daquella Cidade, sua Capitania, e algumas outras do Brazil: feita e ordenada para servir na parte que convier de Elementos para a Historia Brasilica: Ornada de Plantas Geograficas, e Estãpas. Dividida em tres Tomos, que ao Sobrano e Augustissimo Principe Regente N. S., Muito Alto e Muito Poderozo Senhor, Dom Joaõ dedica e offerece o mais humilde dos seus Vassallos Luiz dos Santos Vilhena, Prof $f^{\text {or }}$ Regio de Lingoa Grega na Cid ${ }^{\mathrm{e}}$ da Bahia, Tomo III. Anno de 1802. MS no. 1304881 da Biblioteca Nacional, Rio de Janeiro, p. 309-531.

Received 15/6/2012; accepted 10/11/2012

Editor: Claudio J. B. de Carvalho 